\title{
PENENTUAN JENIS TINDAKAN OPERASI LALU LINTAS BERDASARKAN TINGKAT KERAWANAN LALULINTAS MENGGUNAKAN METODE ANALYTIC HIERARCHY PROCESS DAN VISUALISASI PEMETAAN DI WILAYAH KABUPATEN JEPARA
}

\author{
Ayu Riana Devi Aprilia \\ Fakultas Sains dan Matematika, Departemen Ilmu Komputer / Informatika \\ Universitas Diponegoro \\ Email: ayuriaanada15@gmail.com \\ Indra Waspada \\ Fakultas Sains dan Matematika, Departemen Ilmu Komputer / Informatika \\ Universitas Diponegoro \\ Email: indrawaspada@undip.ac.id
}

\begin{abstract}
ABSTRAK
Jumlah pelanggaran lalu lintas yang terjadi di Indonesia meningkat dari tahun ke tahun. Sejak 2012 hingga 2016, angka pelanggaran melonjak hingga 47 persen. Untuk meningkatkan ketertiban lalu lintas disuatu daerah, aparatur kepolisian memiliki tiga jenis tindakan yaitu penyuluhan, patroli, dan razia. Pada awalnya belum ada metode tertentu yang digunakan atasan dalam memutuskan jenis tindakan disuatu wilayah, hanya berdasarkan pengamatan dari atasan saja, sehingga dalam pelaksanaannya dimungkinkan masih kurang akurat dalam aspek prioritas jenis tindakan yang diambil. Pada penelitian ini telah dibangun suatu sistem menggunakan metode Analytic Hierarchy Process (AHP) yang dapat memberikan informasi lebih cepat dan mudah dipahami dalam penentuan jenis tindakan operasi lalu lintas untuk tiap kecamatan di kabupaten Jepara. Hasil kalkulasi AHP berupa urutan prioritas tindakan. Data-data yang dibutuhkan dalam penghitungan AHP adalah usia pelanggar pelanggar dibawah 17 tahun, usia pelanggar 17 tahun ke atas, dan total kejadian kecelakaan. Untuk memudahkan interaksi dengan pengguna maka hasil urutan prioritas tersebut disajikan dalam bentuk peta yang dapat menampilkan warna merah untuk razia, warna kuning untuk patroli, dan warna hijau untuk penyuluhan. Hasil black box testing menunjukkan bahwa fungsionalitas yang diterapkan pada sistem sudah sesuai, sedangkan hasil dari usability testing menunjukkan sistem dapat diterima oleh pengguna.
\end{abstract}

Kata kunci: pelanggaran lalu lintas, jenis tindakan, analytic hierarchy process.

\section{ABSTRACT}

The number of traffic violations that occurred in Indonesia increased from year to year. From 2012 to 2016, the number of violations jumped to 47 percent. To improve the traffic order in a region, the police apparatus has three types of actions: counseling, patrol, and raid. Initially there is no specific method used by superiors in deciding the type of action in a region, only based on observations from superiors only, so that in its implementation may be still less accurate in the priority aspects of the type of action taken. Therefore, the system has been built using Analytic Hierarchy Process (AHP) method that can provide information more quickly and easily understood in determining the type of traffic operation action for each sub-district in Jepara district. AHP calculation results in the order of action priority. The data required in the calculation of AHP is the age of violator offenders under 17 years, age of violators 17 years and over, and total incidents of accidents. To facilitate interaction with the user then the order of priority results are presented in the form of maps that can display red for raids, yellow for patrols, and green for counselings. The results of black box testing indicate that the functionality applied to the system is appropriate, while the results of usability testing indicate the system accepted by the user.

Keywords: traffic violations, action types, analytic hierarchy process.

\section{PENDAHULUAN}

Pelanggaran hukum adalah tindakan yang menyimpang dari peraturan atau hukum yang berlaku pada suatu Negara. Menurut UUD 1945 Pasal 1 ayat 3 menyebutkan bahwa Negara Indonesia adalah Negara hukum. Oleh karena itu, setiap pelanggaran yang terjadi harus diselesaikan secara hukum. Jumlah 
pelanggaran lalu lintas yang terjadi di Indonesia meningkat dari tahun ke tahun. Sejak 2012 hingga 2016, angka pelanggarannya melonjak sampai 47 persen [1].

Berdasarkan hasil wawancara dengan Kepala Satuan Polisi Lalu Lintas (Kasatlantas) Polres Jepara, jumlah kasus pelanggaran lalu lintas dalam satu tahun terakhir di wilayah Polres Jepara mencapai 18.000 kasus. Data-data kasus pelanggaran tersebut di inputkan polisi ke sistem pusat secara online untuk kemudian dilanjutkan ke pengadilan tanpa adanya pengolahan data. Oleh karena itu, pihak kepolisian masih mengalami kesulitan dalam mengidentifikasi beberapa hal, misalnya lokasi dan jenis pelanggaran lalu lintas yang sering terjadi di suatu wilayah. Tindakan yang dapat dilakukan untuk mengurangi jumlah kasus pelanggaran terbagi menjadi tiga jenis yaitu penyuluhan, patroli dan razia. Menurut Kasatlantas hingga saat ini belum ada metode tertentu yang digunakan atasan dalam pengambilan keputusan terkait jenis tindakan pada lokasi pelanggaran lalu lintas disuatu wilayah, hanya berdasarkan pengamatan dari atasan saja, maka dalam pelaksanaannya dimungkinkan masih kurang akurat dalam aspek prioritas jenis tindakan yang diambil. Oleh karena itu diperlukan metode yang tepat untuk mendukung penentuan tindakan tersebut.

Metode AHP memiliki beberapa kelebihan yaitu memiliki struktur hirarki, konsisten, dan dapat memperhitungkan validitas sampai dengan batas toleransi inkonsistensi berbagai kriteria dan alternatif [2][3]. Implementasi AHP telah banyak digunakan dalam menyelesaikan beberapa jenis masalah spasial seperti perencanaan penggunaan lahan, pemilihan lokasi, pemilihan alternatif keputusan, kepuasan pelanggan [4]. Oleh karena itu, berdasarkan kriteria diatas metode AHP dirasa tepat digunakan sebagai pendukung keputusan penentuan tindakan Polres.

Kriteria yang digunakan oleh pimpinan Polres selama ini dalam memutuskan tindakan di suatu wilayah adalah berdasarkan angka kecelakaan dan angka pelanggaran. Termasuk disini perlu diperhitungkan pelanggaran yang dilakukan oleh anak dibawah 17 tahun. Berdasarkan kriteria-kriteria tersebut, dibangun sistem pendukung keputusan menggunakan metode Analytic Hierarcy Process (AHP). Hasil komputasi AHP kemudian disajikan dalam bentuk tabel, peta berwarna, serta grafik yang dapat memberikan informasi prioritas jenis tindakan yang sesuai pada tiap kecamatan di kabupaten Jepara.

\section{METODOLOGI PENELITIAN} aplikasi.

Metodologi penelitian yang dilakukan mencakup metode pengambilan data dan pengembangan

\subsection{Metode Pengambilan Data}

Metode pengambilan data yang digunakan pada penelitian ini adalah :

\subsubsection{Wawancara}

Data yang diperoleh dari hasil wawancara meliputi kriteria-kriteria yang digunakan untuk membangun sistem pengambilan keputusan yang didukung oleh peraturan kapolri no. 80 tahun 2012 [5]. Kriteria - kriteria yang digunakan untuk menentukan tindakan yaitu banyaknya kecelakaan dan banyaknya pelanggaran lalu lintas itu yang utama. Akan tetapi menurut Kasatlantas, banyaknya pelanggaran yang dilakukan oleh anak dibawah 17 tahun juga dapat dijadikan salah satu kriteria. Oleh karena itu, untuk kriteria banyaknya pelanggaran akan dibagi menjadi dua kriteria yaitu kriteria banyaknya Usia Pelanggar 17 tahun keatasyang dilakukan oleh pelanggar 17 tahun keatas dan usia pelanggar dibawah 17 tahun. Berdasarkan hasil wawancara yang didukung oleh fungsi teknis lalu lintas yang dikeluarkan oleh Markas Besar POLRI [5], dapat diketahui bahwa tindakan / penegakan hukum lalu lintas yang dilakukan kepolisian untuk mengurangi pelanggaran lalu lintas di suatu daerah ada tiga, yaitu tindakan preventif yang merupakan tindakan pengaturan, penjagaan, dan patroli, tindakan represif yang merupakan penindakan hukum terhadap para pelanggar lalu lintas dan penyidikan kecelakaan lalu lintas atau razia kepolisian dan tindakan preemptif yang merupakan sosialisasi / peyuluhan.

\subsubsection{Data Pelanggaran dan Kecelakaan Lalu Lintas Kabupaten Jepara}

Data pelanggaran dan data kecelakaan lalu lintas di Kabupaten Jepara merupakan data berupa file / dokumen excel yang didapatkan dari unit pelayanan tilang / razia dan admin satlantas untuk data kecelakaannya. Pada data pelanggaran terdapat data - data seperti pada Gambar 1. 


\begin{tabular}{|c|c|c|c|c|c|c|c|c|c|c|c|c|}
\hline \multirow[b]{2}{*}{ Lokasi Pelanggaran } & \multirow[b]{2}{*}{ Kecamatan } & \multirow[b]{2}{*}{$\begin{array}{c}\text { Jumlah } \\
\text { Pelanggaran }\end{array}$} & \multicolumn{8}{|c|}{ Pasal Pelanggaran } & \multicolumn{2}{|c|}{ Usia Pelanggar } \\
\hline & & & $\begin{array}{c}\text { Tidak memiliki } \\
\text { SIM }\end{array}$ & $\begin{array}{c}\text { Tidak memiliki } \\
\text { STNK }\end{array}$ & \begin{tabular}{|c|} 
Tidak \\
menggunakan \\
Helm SNI \\
\end{tabular} & $\begin{array}{c}\text { Menerbos } \\
\text { rambu }\end{array}$ & $\begin{array}{c}\text { Tidak } \\
\text { menyalakan } \\
\text { lampu }\end{array}$ & $\begin{array}{c}\text { TNKB } \\
\text { Tidak Sah }\end{array}$ & $\begin{array}{c}\text { Tidak menggunakan } \\
\text { sabuk pengaman }\end{array}$ & DII & $\begin{array}{l}\text { dibawah } \\
17 \text { tahun }\end{array}$ & $\begin{array}{c}\text { diatas } 17 \\
\text { tahun }\end{array}$ \\
\hline Jl. Ratu Kalinyamat & Kalinyamatan & 77 & 43 & 12 & 15 & & & 2 & 5 & & 22 & 55 \\
\hline Jl. Batu Kali & Kalinyamatan & 94 & 57 & 16 & 9 & 2 & 4 & & 3 & 3 & 14 & 80 \\
\hline J1. Jepara - Bangsri & Jepara & 111 & 65 & 20 & 7 & & 5 & & 14 & & 13 & 98 \\
\hline Jl.Shima & Jepara & 121 & 78 & 21 & 8 & & 2 & 4 & 6 & 2 & 22 & 99 \\
\hline Jl. Damaran - Pecangaan & Pecangaan & 110 & 61 & 18 & 16 & 2 & 4 & 3 & 4 & 2 & 24 & 86 \\
\hline
\end{tabular}

Gambar 19. Data Pelanggaran Lalu Lintas (sumber: Polres jepara)

Data yang digunakan pada sistem adalah data pelanggaran lalu lintas menurut usia yaitu usia dibawah 17 tahun dan 17 tahun keatas. Selain data pelanggaran, digunakan pula jumlah data kecelakaan yang diperoleh dari tabel data kecelakaan yang dapat dilihat pada Gambar 2.

\begin{tabular}{|c|c|c|c|c|c|c|c|c|c|c|c|}
\hline \multirow[b]{2}{*}{ No } & \multirow[b]{2}{*}{ Lokasi Kecelakaan } & \multirow[b]{2}{*}{ Kecamatan } & \multirow[b]{2}{*}{ Jumlah } & \multirow{2}{*}{$\begin{array}{c}\text { Meninggal } \\
\text { Dunia }\end{array}$} & \multirow{2}{*}{$\begin{array}{l}\text { Luka } \\
\text { Berat }\end{array}$} & \multirow{2}{*}{$\begin{array}{l}\text { Luka } \\
\text { Ringan }\end{array}$} & \multirow{2}{*}{$\begin{array}{l}\text { Tidak } \\
\text { Luka }\end{array}$} & \multirow{2}{*}{$\begin{array}{c}\text { Belum } \\
\text { Diketahui }\end{array}$} & \multicolumn{3}{|c|}{ Jenis Kelamin } \\
\hline & & & & & & & & & Laki - Laki & Perempuan & $\begin{array}{c}\text { belum } \\
\text { diketahui }\end{array}$ \\
\hline 1 & Perempatan Jl. Mayong & Mayong & 100 & 8 & & 14 & 78 & & 69 & 31 & \\
\hline 2 & Tikungan Margoyoso & Kalinyamatan & 112 & 55 & & 34 & 15 & 8 & 76 & 34 & 2 \\
\hline 3 & Jl. Mlonggo - Bondo & Mlonggo & 15 & 2 & & 2 & 11 & & 9 & 6 & \\
\hline 4 & Jl. Raya Margoyoso & Kalinyamatan & 89 & 11 & & 40 & 38 & 2 & 53 & 36 & \\
\hline
\end{tabular}

Gambar 20. Data Kecelakaan (sumber: Polres jepara)

Pada data pelanggaran lalu lintas dapat terlihat bahwa satu nama jalan melintasi beberapa kecamatan demikian pula sebaliknya satu kecamatan terdapat beberapa nama jalan. Contoh data lokasi pelanggaran dapat dilihat pada Tabel 1.

Tabel 1. Contoh data lokasi pelanggaran

\begin{tabular}{lll}
\hline No & Lokasi Pelanggaran & Kecamatan \\
\hline 1. & Jl. Batu Kali & Kalinyamatan \\
2. & Jl. Jepara-Bangsri & Jepara \\
3. & Jl. Mlonggo - Bondo & Mlonggo \\
4. & Jl. Jepara - Bangsri & Bangsri \\
\hline
\end{tabular}

\subsubsection{Data Lokasi}

Data lokasi yang didapatkan merupakan peta Kabupaten Jepara yang berekstensi .jpg [7] dan peta ini dijadikan acuan pada saat melakukan digitasi peta dengan menggunakan ArcGIS 10.3. Peta yang didapatkan memuat nama - nama kecamatan di Kabupaten Jepara.

\subsection{Pengembangan Aplikasi}

Pengembangan aplikasi dikerjakan sebagai berikut :

\subsubsection{Sistem Informasi Geografis Daerah Rawan Pelanggaran}

Berdasarkan data yang telah didapatkan pada tahap pengambilan data, penentuan daerah rawan pelanggaran lalu lintas di Kabupaten Jepara diolah dengan menggunakan metode AHP dan kemudian dilakukan perangkingan dan divisualisasikan dengan sistem informasi geografis.

Data pelanggaran lalu lintas maupun data lokasi yang telah dikumpulkan sebelumnya, dilakukan proses AHP untuk menentukan tindakan terhadap lokasi pelanggaran lalu lintas di Kabupaten Jepara. Sebelum data diproses dengan menggunakan metode AHP, pertama perlu menginputkan data dari tiap kriteria pada tiap alternatif yang kemudian akan dibentuk suatu matriks berpasangan. Berdasarkan hasil wawancara yang telah dilakukan yang didukung peraturan kapolri no 80 tahun 2012 [5] kriteria - kriteria yang digunakan untuk menentukan tindakan preventif, represif, dan preemptif [6] adalah:

a. Usia Pelanggar dibawah 17 tahun

Usia pelanggar dapat sebagai salah satu penentu jenis tindakan yang harus dilakukan. Misalnya saja apabila rata - rata usia pelanggar kurang dari 17 tahun / dibawah umur pada suatu lokasi banyak maka dapat dilakukan tindakan preemptif di sekolah - sekolah. 
b. Usia Pelanggar 17 Tahun Keatas

Salah satu faktor utama yang dapat menentukan jenis tindakan pada pelanggaran lalu lintas disuatu daerah adalah pada banyaknya pelanggaran yang terjadi disuatu daerah. Hal ini didukung dengan data - data mengenai tingkat/usia pelanggar 17 tahun keatas yang telah digunakan. Karena semakin banyak pelanggaran yang terjadi maka daerah tersebut semakin rawan. Pada kriteria ini, usia 17 tahun diaggap sudah diperbolehkan mengendarai kendaran dan memiki SIM (Surat Izin Mengemudi), apabila pelanggaran lalu lintas yang dilakukan pada jenjang usia ini sering terjadi disuatu daerah maka tindakn yag mungkin dlakkukan oleh kepolisian ialah razia.

c. Kejadian Kecelakaan

Selain tingkat kecelakaan faktor lain yang dapat menentukan jenis tindakan adalah banyaknya kecelakaan. Hal ini didukung dengan data - data mengenai tingkat/Kejadian Kecelakaan yang telah digunakan. Semakin banyak kecelakaan yang terjadi di suatu daerah maka makin rawan daerah tersebut.

Berdasarkan kriteria tersebut, tiap- tiap kriteria akan dilakukan perbandingan matriks berpasangan dengan menggunakan skala kepentingan Saaty. Perbandingan kriteria Usia Pelanggar 17 tahun keatasdengan kejadian kecelakan adalah sama pentingnya (1), perbandingan kriteria Usia Pelanggar 17 tahun keatas dengan Usia Pelanggar dibawah 17 tahun adalah sedikit lebih penting (3), dan perbandingan kriteria kejadian kecelakan dengan Usia Pelanggar dibawah 17 tahun adalah lebih penting dari (5) . Masing - masing perbandingan kriteria ini berdasarkan hasil wawancara pada Lampiran 5. Kemudian tiap - tiap matriks perbandingan kriteria berpasangan tersebut dilakukan normalisasi untuk menentukan nilai bobot prioritasnya. Apabila nilai CR-nya lebih dari 0.1 maka proses akan mengulangi dari awal penginputan kriteria. Apabila nilai CR kurang dari 0.1 maka perbandingan kriteria tersebut konsisten. Kemudian akan dilakukan pehitungan pada tiap - tiap alternatif untuk mencari nilai bobot prioritasnya. Lalu, setelah didapatkan bobot prioritas masing - masing alternatif, dilakukan perhitungan hasil akhir yang kemudian akan ditampilkan output berupa hasil akhir masing-masing alternatif. Alur proses metode Analytic Hierarchy Process (AHP) disajikan pada Gambar 3.

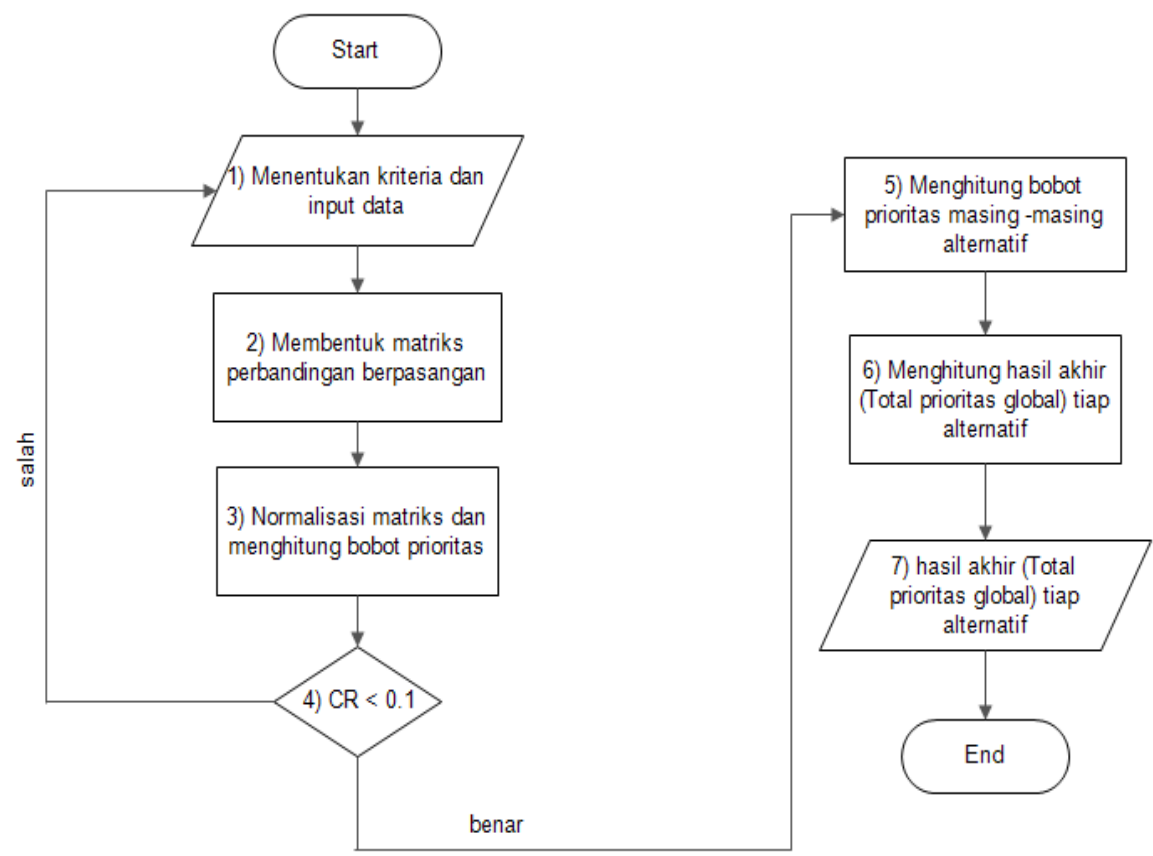

Gambar 21. Flowchart Metode AHP

\subsubsection{Digitasi Peta}

Digitasi peta merupakan pembentukan peta digital dengan mengubah peta analog. Peta analog yang digitasi adalah peta Kabupaten Jepara yang berformat .jpg dengan bantuan aplikasi ArcGIS 10.3. 


\section{HASIL DAN PEMBAHASAN}

\subsection{Analisa Perhitungan Metode AHP}

Untuk mengetahui jalannya flowchart metode Analytic Hierarchy Process dapat dilihat pada Perhitungan Metode Analytic Hierarchy Process berikut:

\subsubsection{Menentukan Kriteria}

Sistem Pendukung Keputusan Rekomendasi Jenis Tindakan terhadap Lokasi Pelanggaran Lalu Lintas di Kabupaten Jepara Menggunakan Metode Analytic Hierarchy Process dan Visual Pemetaan dengan GIS terdapat beberapa kriteria yang digunakan antara lain jumlah pelanggaran, jumlah kecelakaan, dan jumlah pelanggar dibawah umur. Pertama-tama sebelum dihasilkan jenis rekomendasinya, dilakukan perangkingan daerah rawan pelanggaran lalu lintas. Hirarki penentuan daerah rawan pelanggaran lalu lintas dapat dilihat pada Gambar 4.

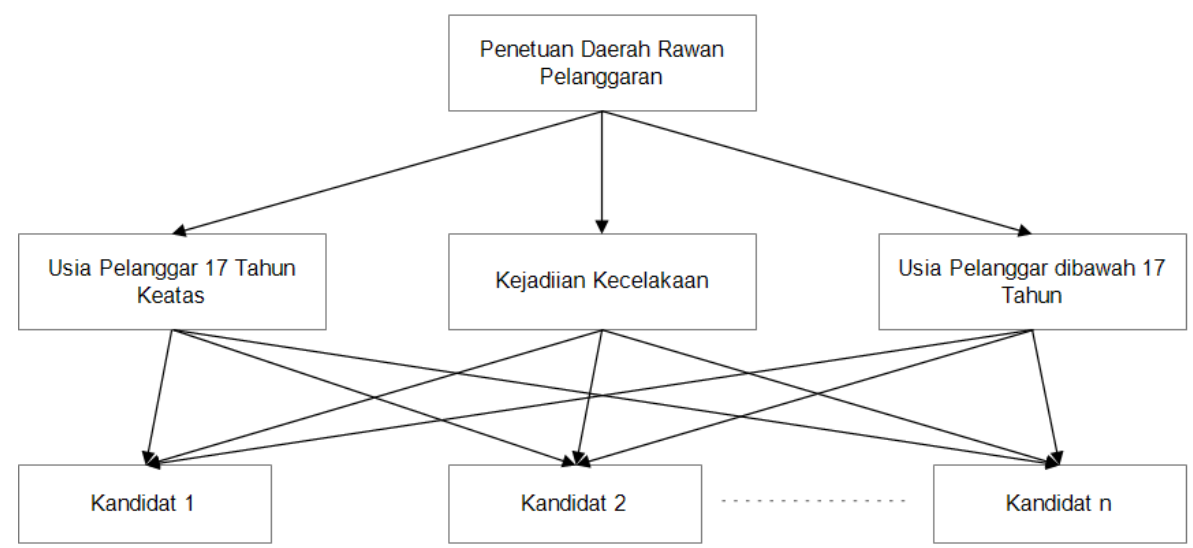

Gambar 22. Hirarki Penentuan Daerah Rawan Pelanggaran Lalu Lintas

Sampel data yang digunakan pada contoh perhitungan metode AHP adalah sampel data pada tahun 2016. Sampel data yang digunakan untuk contoh perhitungan adalah berjumlah 10 sampel yang merupakan daerah - daerah yang paling sering terjadi pelanggaran lalu lintas.

\begin{tabular}{|c|c|c|c|}
\hline No & $\begin{array}{l}\text { Lokasi } \\
\text { Pelanggaran }\end{array}$ & Kecamatan & Data Kriteria \\
\hline 1 & Jl. Batu Kali & Kalinyamatan & $\begin{array}{l}\text { Usia Pelanggar } 17 \text { tahun keatas: } 168 \\
\text { Usia Pelanggar dibawah } 17 \text { tahun: } 32 \\
\text { Kejadian Kecelakaan : } 100\end{array}$ \\
\hline 2 & $\begin{array}{l}\text { J1. Damaran- } \\
\text { Pecangaan }\end{array}$ & Pecangaan & $\begin{array}{l}\text { Usia Pelanggar } 17 \text { tahun keatas: } 36 \\
\text { Usia Pelanggar dibawah } 17 \text { tahun: } 18 \\
\text { Kejadian Kecelakaan : } 32\end{array}$ \\
\hline 3 & J1. Pasar-Batealit & Batealit & $\begin{array}{l}\text { Usia Pelanggar } 17 \text { tahun keatas: } 28 \\
\text { Usia Pelanggar dibawah } 17 \text { tahun: } 42 \\
\text { Kejadian Kecelakaan : } 25\end{array}$ \\
\hline 4 & Jl. Pemuda & Kedung & $\begin{array}{l}\text { Usia Pelanggar } 17 \text { tahun keatas: } 58 \\
\text { Usia Pelanggar dibawah } 17 \text { tahun: } 7 \\
\text { Kejadian Kecelakaan : } 80\end{array}$ \\
\hline 5 & Jl. Raya Pecangaan & Pecangaan & $\begin{array}{l}\text { Usia Pelanggar } 17 \text { tahun keatas: } 85 \\
\text { Usia Pelanggar dibawah } 17 \text { tahun: } 35 \\
\text { Kejadian Kecelakaan : } 78\end{array}$ \\
\hline 6 & $\begin{array}{l}\text { Jl. Raya } \\
\text { Purwogondo }\end{array}$ & Kalinyamatan & $\begin{array}{l}\text { Usia Pelanggar } 17 \text { tahun keatas: } 154 \\
\text { Usia Pelanggar dibawah } 17 \text { tahun: } 87 \\
\text { Kejadian Kecelakaan : } 110\end{array}$ \\
\hline 7 & Jl. Raya Margoyoso & Mayong & $\begin{array}{l}\text { Usia Pelanggar } 17 \text { tahun keatas: } 161 \\
\text { Kejadian Kecelakaan : } 157 \\
\text { Usia Pelanggar dibawah } 17 \text { tahun: } 54\end{array}$ \\
\hline
\end{tabular}




\begin{tabular}{|c|c|c|c|}
\hline No & $\begin{array}{l}\text { Lokasi } \\
\text { Pelanggaran }\end{array}$ & Kecamatan & Data Kriteria \\
\hline 8 & Jl. Ratu Kalinyamat & Kalinyamatan & $\begin{array}{l}\text { Usia Pelanggar } 17 \text { tahun keatas: } 66 \\
\text { Usia Pelanggar dibawah } 17 \text { tahun: } 47 \\
\text { Kejadian Kecelakaan : } 63\end{array}$ \\
\hline 9 & $\begin{array}{l}\text { Tikungan } \\
\text { Margoyoso }\end{array}$ & Kalinyamatan & $\begin{array}{l}\text { Usia Pelanggar } 17 \text { tahun keatas: } 149 \\
\text { Usia Pelanggar dibawah } 17 \text { tahun: } 43 \\
\text { Kejadian Kecelakaan : } 78\end{array}$ \\
\hline 10 & Jl. Tirto Samudro & Jepara & $\begin{array}{l}\text { Usia Pelanggar } 17 \text { tahun keatas: } 57 \\
\text { Usia Pelanggar dibawah } 17 \text { tahun: } 43 \\
\text { Kejadian Kecelakaan : } 132\end{array}$ \\
\hline
\end{tabular}

\subsubsection{Menetapkan Nilai Matriks Perbandingan Berpasangan}

Setelah menentukan masalah dan kriteria, langkah selanjutnya adalah membentuk matriks perbandingan berpasangan antar kriteria. Nilai diagonal matriks untuk perbandingan berpasangan suatu elemen diisi dengan nilai 1 sedangkan yang lainnya diisi dengan nilai perbandingan antara 1 sampai 9 kemudian dijumlahkan perkolom. Kriteria Usia Pelanggar 17 tahun keatassama pentingnya dengan Kejadian Kecelakaan dan sedikit lebih penting dari usia pelanggar dibawah 17 tahun. Kriteria Kejadian Kecelakaan lebih penting dari usia pelanggar dibawah 17 tahun.

Tabel 2. Matriks perbandingan kriteria

\begin{tabular}{lcccc}
\hline Kriteria & $\begin{array}{l}\text { Usia } \\
\text { 17 tahun keatas }\end{array}$ & $\begin{array}{l}\text { Pelanggar } \\
\text { dibawah 17 tahun }\end{array}$ & $\begin{array}{c}\text { Kelanggadian } \\
\text { Kecelakaan }\end{array}$ \\
\hline $\begin{array}{l}\text { Usia Pelanggar } \\
\text { tahun keatas }\end{array}$ & 1 & 3 & 1 \\
$\begin{array}{l}\text { Usia pelanggar } \\
\text { dibawah 17 tahun }\end{array}$ & $1 / 3$ & 1 & $1 / 5$ \\
$\begin{array}{l}\text { Kejadian } \\
\text { Kecelakaan }\end{array}$ & 1 & 5 & 1 \\
Jumlah & 2.3333333 & & \\
\hline
\end{tabular}

\subsubsection{Menghitung Bobot Prioritas Kriteria}

Setelah terbentuk matriks perbandingan, maka langkah selanjutnya adalah dengan menghitung bobot prioritas kriteria yaitu dengan membagi isi matriks perbandingan dengan jumlah kolom bersesuaian.

Tabel 3. Matriks bobot kriteria

\begin{tabular}{|c|c|c|c|c|}
\hline \multirow[t]{2}{*}{ Kriteria } & \multirow{2}{*}{$\begin{array}{l}\text { Usia } \\
\text { Pelanggar } 17 \\
\text { tahun keatas }\end{array}$} & Usia pelanggar & \multirow{2}{*}{$\begin{array}{l}\text { Kejadian } \\
\text { Kecelakaa } \\
n\end{array}$} & \multirow{2}{*}{$\begin{array}{l}\text { Bobot } \\
\text { Prioritas }\end{array}$} \\
\hline & & $\begin{array}{ll}\text { dibawah } & 17 \\
\text { tahun }\end{array}$ & & \\
\hline ar 17 & 8 & $\begin{array}{c}0.33333333333 \\
333\end{array}$ & $\begin{array}{c}0.4545454 \\
54\end{array}$ & $\begin{array}{c}105483 \\
4\end{array}$ \\
\hline $\begin{array}{l}\text { Usia pelanggar } \\
\text { dibawah } 17 \text { tahun }\end{array}$ & 0.1428571 & $\begin{array}{c}0.11111111111 \\
111\end{array}$ & $\begin{array}{c}0.0909090 \\
90\end{array}$ & $\begin{array}{c}0.114959 \\
1\end{array}$ \\
\hline $\begin{array}{l}\text { Kejadian } \\
\text { Kecelakaan }\end{array}$ & 0.428571428 & $\begin{array}{c}0.555555555555 \\
556\end{array}$ & $\begin{array}{c}0.4545454 \\
54\end{array}$ & $\begin{array}{c}0.479557 \\
4\end{array}$ \\
\hline
\end{tabular}

\subsubsection{Menghitung Konsistensi Kriteria}

Penghitungan konsistensi matriks perbandingan dilakukan melalui perkalian seluruh isi kolom matriks perbandingan A dengan bobot prioritas kriteria A, isi kolom matriks perbandingan B dengan bobot prioritas kriteria B dan seterusnya. Kemudian dijumlahkan barisnya dan dibagi dengan bobot prioritas. Formula yang digunakan dalam penghitungan konsistensi kriteria disajikan pada rumus (1) dan rasio konsistensi pada rumus (2). 
$C I=\frac{\left(\lambda_{\max }-n\right)}{(n-1)}$

Dengan :

CI : Rasio penyimpangan konsistensi (consistency index)

$\lambda_{\max } \quad$ : Nilai rata-rata eigen

n : Orde matriks

$C R=\frac{C I}{R I}$

(2)

Dengan :

$\mathrm{CR}=$ Rasio Konsistensi

RI = Indeks Random

Dengan menggunakan rumus (1) maka diperoleh hasil penghitungan sebagai berikut:

Hitung $\lambda$ maks $=(2.333333333 \times 0.4054834)+(2.2 \times 0.4795574)+(9 \times 0.1149591)=3.0357864$

Hitung $C I=\frac{(\lambda \max -n)}{(n-1)}=\frac{3,0357864-3}{3-1}=0.01789$

Mengacu pada nilai RI untuk $\mathrm{n}=3$ adalah 0,58 [4], maka dengan menggunakan rumus (2) dapat diperoleh hasil penghitungan sebagai berikut:

$\mathrm{CR}=\frac{C I}{R I}=\frac{0.01789}{0,58}=0.03085$

Dengan hasil yang menunjukkan bahwa $\mathrm{CR}<0,1$ artinya telah diperoleh preferensi pembobotan yang konsisten.

\subsubsection{Menentukan Matriks Perbandingan Lokasi Masing - Masing Kriteria}

a. Untuk Usia Pelanggar 17 tahun keatas

Karena data yang digunakan bukan merupakan matriks berpasangan melainkan data kuantitatif sehingga untuk menhasilkan bobot prioritas dilakukan dengan cara membagi nilai masing masing kandidat dengan jumlah totalnya[8].

Tabel 4. Matriks Perbandingan Usia Pelanggar 17 tahun Keatas

\begin{tabular}{lcl}
\hline $\begin{array}{l}\text { Usia Pelanggar 17 tahun } \\
\text { keatas }\end{array}$ & $\begin{array}{c}\text { Data } \\
\text { Pelanggaran }\end{array}$ & Bobot Prioritas \\
\hline Jl. Batu Kali & 168 & $168 / 962=0.1746361$ \\
J1. Damaran-Pecangaan & 36 & $36 / 962=0.0374220$ \\
Jl. Pasar-Batealit & 28 & $28 / 962=0.029106029$ \\
Jl. Pemuda & 58 & $58 / 962=0.06029106$ \\
Jl. Raya Pecangaan & 85 & $85 / 962=0.08835758$ \\
Jl. Raya Purwogondo & 154 & $154 / 962=0.1600831$ \\
Jl. Raya Margoyoso & 161 & $161 / 962=0.16735966$ \\
Jl. Ratu Kalinyamat & 66 & $66 / 962=0.06860706$ \\
Tikungan Margoyoso & & $149 / 962=$ \\
Jl. Tirto Samudro & 149 & 0.15488565 \\
\hline Jumlah & 57 & $57 / 962=0.059251559$ \\
\hline
\end{tabular}

b. Untuk kriteria Usia Pelanggar dibawah 17 tahun

Data yang digunakan bukan merupakan matriks berpasangan melainkan data kuantitatif sehingga untuk menhasilkan bobot prioritas dilakukan dengan cara membagi nilai masing - masing kandidat dengan jumlah totalnya [8]. 
Tabel 5. Matriks perbandingan usia pelanggar dibawah 17 tahun

\begin{tabular}{lcc}
\hline Usia Pelanggar dibawah & Data Pelanggaran & Bobot Prioritas \\
$\mathbf{1 7}$ tahun & & \\
\hline Jl. Batu Kali & 32 & 0.078431373 \\
Jl. Damaran-Pecangaan & 18 & 0.044117647 \\
Jl. Pasar-Batealit & 42 & 0.102941176 \\
Jl. Pemuda & 7 & 0.017156863 \\
Jl. Raya Pecangaan & 35 & 0.085784314 \\
Jl. Raya Purwogondo & 87 & 0.213235294 \\
Jl. Raya Margoyoso & 54 & 0.132352941 \\
Jl. Ratu Kalinyamat & 47 & 0.115196078 \\
Tikungan Margoyoso & 43 & 0.105392157 \\
Jl. Tirto Samudro & 43 & 0.105392157 \\
\hline Jumlah & $\mathbf{4 0 8}$ & \\
\hline
\end{tabular}

c. Untuk kriteria Kejadian Kecelakaan

Data yang digunakan bukan merupakan matriks berpasangan melainkan data kuantitatif sehingga untuk menhasilkan bobot prioritas dilakukan dengan cara membagi nilai masing - masing kandidat dengan jumlah totalnya [8].

Tabel 6. Matriks perbandingan kejadian kecelakaan

\begin{tabular}{lcc}
\hline Kejadian Kecelakaan & $\begin{array}{c}\text { Data } \\
\text { Pelanggaran }\end{array}$ & Bobot Prioritas \\
\hline Jl. Batu Kali & 100 & 0.116959064 \\
Jl. Damaran-Pecangaan & 32 & 0.037426901 \\
Jl. Pasar-Batealit & 25 & 0.029239766 \\
Jl. Pemuda & 80 & 0.093567251 \\
Jl. Raya Pecangaan & 78 & 0.09122807 \\
Jl. Raya Purwogondo & 110 & 0.128654971 \\
Jl. Raya Margoyoso & 157 & 0.183625731 \\
Jl. Ratu Kalinyamat & 63 & 0.073684211 \\
Tikungan Margoyoso & 78 & 0.09122807 \\
Jl. Tirto Samudro & 132 & 0.154385965 \\
\hline Jumlah & $\mathbf{8 5 5}$ & \\
\hline
\end{tabular}

\subsubsection{Menentukan Matriks Total Prioritas Global}

Untuk menentukan skor akhir perhitungan AHP dengan cara perkalian matriks bobot prioritas masing - masing kriteria terhadap kandidat lokasi rawan pelangaran dengan bobot prioritas perbandingan berpasangan.

Tabel 7. Metriks total prioritas global

\begin{tabular}{lcccc}
\hline & $\begin{array}{c}\text { Usia Pelanggar } \\
\text { 17 tahun keatas }\end{array}$ & $\begin{array}{c}\text { Usia pelanggar } \\
\text { dibawah 17 tahun }\end{array}$ & $\begin{array}{c}\text { Kejadian } \\
\text { Kecelakaan }\end{array}$ & $\begin{array}{c}\text { Hasil } \\
\text { Akhir }\end{array}$ \\
\hline Jl. Batu Kali & 0.174636175 & 0.07843 & 0.116959 & 0.1359 \\
& $\mathrm{X} 0.4054834$ & $\mathrm{x} 0.1149591$ & $\mathrm{x} 0.4795574$ & 17 \\
Jl. Damaran- & $0.037422037 \mathrm{x}$ & $0.04411764 \mathrm{x}$ & $0.0374269 \mathrm{x}$ & 0.0381 \\
Pecangaan & 0.4054834 & 0.1149591 & 0.4795574 & 94 \\
Jl. Pasar- & $0.029106029 \mathrm{x}$ & $0.10294117 \mathrm{x}$ & $0.0292397 \mathrm{x}$ & 0.0376 \\
Batealit & 0.4054834 & 0.1149591 & 0.4795574 & 58 \\
Jl. Pemuda & $0.06029106 \mathrm{x}$ & $0.01715686 \mathrm{x}$ & $0.0935672 \mathrm{x}$ & 0.0712 \\
& 0.4054834 & 0.1149591 & 0.4795574 & 9 \\
Jl. Raya & $0.088357 \mathrm{x}$ & $0.08578431 \mathrm{x}$ & $0.0912280 \mathrm{x}$ & 0.0894 \\
Pecangaan & 0.4054834 & 0.1149591 & 0.4795574 & 39 \\
Jl. Raya & $0.160083 \mathrm{x}$ & $0.21323529 \mathrm{x}$ & $0.1286549 \mathrm{x}$ & 0.1511 \\
Purwogondo & 0.4054834 & 0.1149591 & 0.4795574 & 21
\end{tabular}




\begin{tabular}{lcccc}
\hline & $\begin{array}{c}\text { Usia Pelanggar } \\
\text { 17 tahun keatas }\end{array}$ & $\begin{array}{c}\text { Usia pelanggar } \\
\text { dibawah 17 tahun }\end{array}$ & $\begin{array}{c}\text { Kejadian } \\
\text { Kecelakaan }\end{array}$ & $\begin{array}{c}\text { Hasil } \\
\text { Akhir }\end{array}$ \\
\hline Jl. Raya & $0.167359 \times$ & $0.13235294 \times$ & $0.1836257 \times$ & 0.1711 \\
Margoyoso & 0.4054834 & 0.1149591 & 0.4795574 & 36 \\
Jl. Ratu & $0.068607 \times$ & $0.11519607 \times$ & $0.0736842 \times$ & 0.0763 \\
Kalinyamat & 0.4054834 & 0.1149591 & 0.4795574 & 98 \\
Tikungan & $0.154885 \times$ & $0.10539215 \times$ & $0.0912280 \times$ & 0.1186 \\
Margoyoso & 0.4054834 & 0.1149591 & 0.4795574 & 69 \\
Jl. Tirto & $0.059251 \times$ & $0.10539215 \times$ & $0.1543859 \times$ & 0.1101 \\
Samudro & 0.4054834 & 0.1149591 & 0.4795574 & 79 \\
\hline
\end{tabular}

Setelah didapatkan hasil akhir, kemudian dapat dilakukan perangkingan dari yang terbesar hingga yang terkecil. Lokasi yang memiliki nilai terbesar merupakan daerah yang rawan pelanggaran lalu lintas begitupula sebaliknya. Sehingga untuk menentukan rekomendasi jenis tindakan yang dilakukan dapat dihasilkan dengan cara membandingkan hasil akhir lokasi dengan parameter tiap - tiap rekomendasi.

\subsection{Perangkingan Daerah Rawan Pelanggaran}

Melalui SPK AHP diperoleh hasil akhir perhitungan metode AHP , kemudian dari hasil tersebut akan dilakukan perangkingan masing - masing lokasi pelanggaran per tahun.

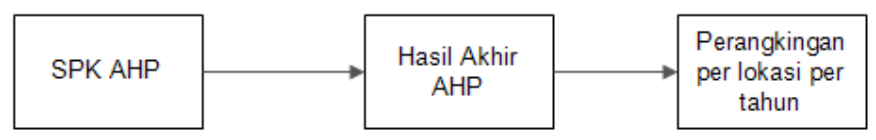

Gambar 23. Alur SPK

Hasil akhir dari perhitungan AHP dapat dilihat pada Tabel 8.

Tabel 8. Perangkingan hasil akhir

\begin{tabular}{llcc}
\hline No & Lokasi Pelanggaran & Hasil Akhir & Rangking \\
\hline 1. & Jl. Batu Kali & 0.135917 & 3 \\
2. & Jl. Damaran-Pecangaan & 0.038194 & 9 \\
3. & Jl. Pasar-Batealit & 0.037658 & 10 \\
4. & Jl. Pemuda & 0.07129 & 8 \\
5. & Jl. Raya Pecangaan & 0.089439 & 6 \\
6. & Jl. Raya Purwogondo & 0.151121 & 2 \\
7. & Jl. Raya Margoyoso & 0.171136 & 1 \\
8. & Jl. Ratu Kalinyamat & 0.076398 & 7 \\
9. & Tikungan Margoyoso & 0.118669 & 4 \\
10. & Jl. Tirto Samudro & 0.110179 & 5 \\
\hline
\end{tabular}

\subsection{Pemetaan Rangking Berdasar Kecamatan}

Setelah dilakukan perangkingan masing- masing lokasi per tahun, hasil akhir tersebut digunakan untuk melakukan perangkingan per kecamatan. Kemudian untuk mendapatkan rekomendasi jenis tindakan di suatu wilayah, maka nilai pada peringkat tiap - tiap kecamatan akan ditentukan batas rentangnya (range) yang menunjukkan jenis tindakan yang bersesuaian yaitu warna merah untuk razia, warna kuning untuk patroli dan warna hijau untuk penyuluhan.

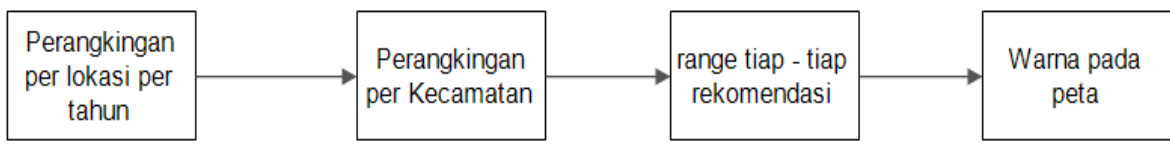

Gambar 24. Alur Pemetaan Rangking Berdasar Kecamatan 
Contoh perangkingan berdasarkan kecamatan ini dapat dilihat pada Tabel 9. yang merupakan data sampel pada tahun 2016.

Tabel 9. Perangkingan per kecamatan

\begin{tabular}{llll}
\hline No & Rangking & Kecamatan & Hasil Akhir \\
\hline 1. & 1 & Kalinyamatan & 0.58052763063 \\
2. & 2 & Pecangaan & 0.112273938266 \\
3. & 3 & Jepara & 0.095915646022 \\
4. & 4 & Kedung & 0.062695863637 \\
5. & 5 & Pakis Haji & 0.050619871870 \\
\hline
\end{tabular}

Kecamatan pada posisi rangking 1 adalah kecamatan Kalinyamatan, memiliki lima jalan yaitu Jl. Batu kali, Jl. Raya Purwogondo, Jl. Raya Margoyoso, Jl. Ratu kalinyamat, dan tikungan Margoyoso yang masing - masing jalan memiliki data - data yang dapat dilihat pada Tabel 10. Berdasarkan data tersebut, dapat dianalisa bahwa rata-rata pelanggaran yang dilakukan oleh kelompok usia 17 tahun keatas dan kejadian kecelakaan menunjukkan angka yang jauh lebih tinggi dibandingkan pelanggar dibawah 17 tahun.

Tabel 10. Data kecamatan kalinyamatan

\begin{tabular}{llccc}
\hline No. & Lokasi Pelanggaran & $\begin{array}{l}\text { Usia pelanggar } \\
\text { 17 tahun keatas }\end{array}$ & $\begin{array}{l}\text { Usia pelanggar } \\
\text { dibawah 17 } \\
\text { tahun }\end{array}$ & $\begin{array}{l}\text { Kejadian } \\
\text { Kecelakaan }\end{array}$ \\
\hline 1. & Jl. Batu kali & 168 & 32 & 100 \\
2. & Jl. Raya Purwogondo & 154 & 87 & 110 \\
3. & Jl. Raya Margoyoso & 161 & 54 & 157 \\
4. & Jl. Ratu kalinyamat & 66 & 47 & 63 \\
5. & Tikungan Margoyoso & 149 & 43 & 78 \\
\hline
\end{tabular}

Sebaliknya, pada kecamatan Pakis Haji yang berada pada posisi rangking 5, memiliki 2 jalan yaitu Jl. Kawak - Lb dan Perempatan Slagi yang masing - masing jalan memiliki data - data yang dapat dilihat pada Tabel 11. Berdasarkan data tersebut, dapat dianalisa bahwa secara umum angka pelanggaran dan kejadian kecelakaan rendah.

Tabel 11. Data kecamatan pakis haji

\begin{tabular}{llccc}
\hline No. & Lokasi Pelanggaran & $\begin{array}{l}\text { Usia } \\
\text { pelanggar 17 } \\
\text { tahun keatas }\end{array}$ & $\begin{array}{l}\text { Usia pelanggar } \\
\text { dibawah 17 } \\
\text { tahun }\end{array}$ & $\begin{array}{l}\text { Kejadian } \\
\text { Kecelakaan }\end{array}$ \\
\hline 1. & Jl. Kawak - Lb & 20 & 20 & 21 \\
2. & Perempatan Slagi & 10 & 12 & 44 \\
\hline
\end{tabular}

Tindakan razia biasanya dilakukan apabila angka pelanggaran usia 17 tahun keatas dan kejadian kecelakaan cukup tinggi dibanding pelanggar dibawah 17 tahun. Sedangkan tindakan penyuluhan dilakukan apabila angka pelanggaran usia dibawah 17 tahun relatif menonjol dibandingkan pelanggar 17 tahun keatas.

Berdasarkan analisa tersebut, hasil akhir yang bernilai lebih dari 0.2 akan menghasilkan warna merah sebagai rekomendasi tindakan razia sedangkan hasil akhir yang bernilai antara 0.01 hingga kurang dari 0.08 diberi warna hijau sebagai rekomendasi tindakan penyuluhan. Untuk range antara 0.08 hingga 0.2 adalah warna kuning yaitu rekomendasi jenis tindakan patroli.

\subsection{Hasil Implementasi}

Pada bagian ini disajikan hasil implementasi sistem yang meliputi antarmuka halaman hasil akhir, antarmuka halaman pemetaan per kecamatan, dan antarmuka peta rekomendasi jenis tindakan. 
a. Antarmuka Halaman Hasil Akhir

Pada antarmuka ini disajikan tabel hasil perangkingan data - data pelanggaran lalu lintas di tiaptiap lokasi/jalan yang dapat dipilih berdasarkan tahunnya. Implementasi antarmuka halaman hasil akhir dapat dilihat pada Gambar 6.

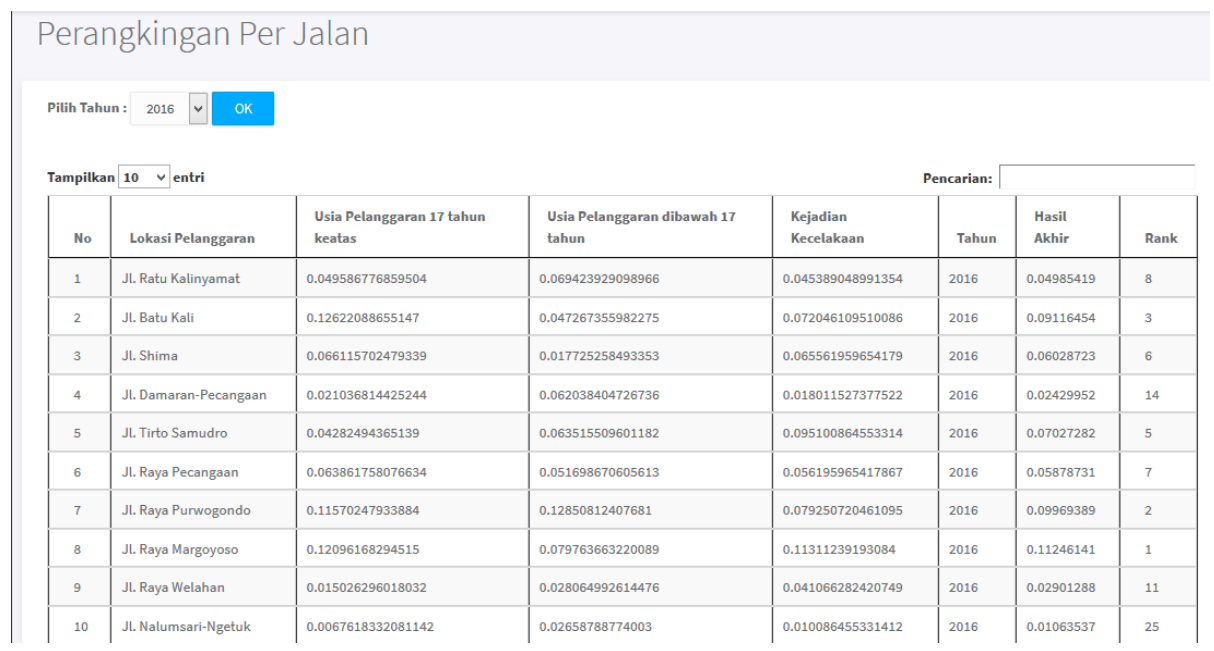

Gambar 6. Antarmuka Halaman Hasil Akhir

b. Antarmuka Halaman Pemetaan Per Kecamatan

Pada antarmuka ini disajikan tabel hasil perangkingan data - data pelanggaran lalu lintas di tiaptiap kecamatan yang dapat dipilih berdasarkan tahunnya. Implementasi antarmuka pemetaan per kecamatan dapat dilihat pada Gambar 7.

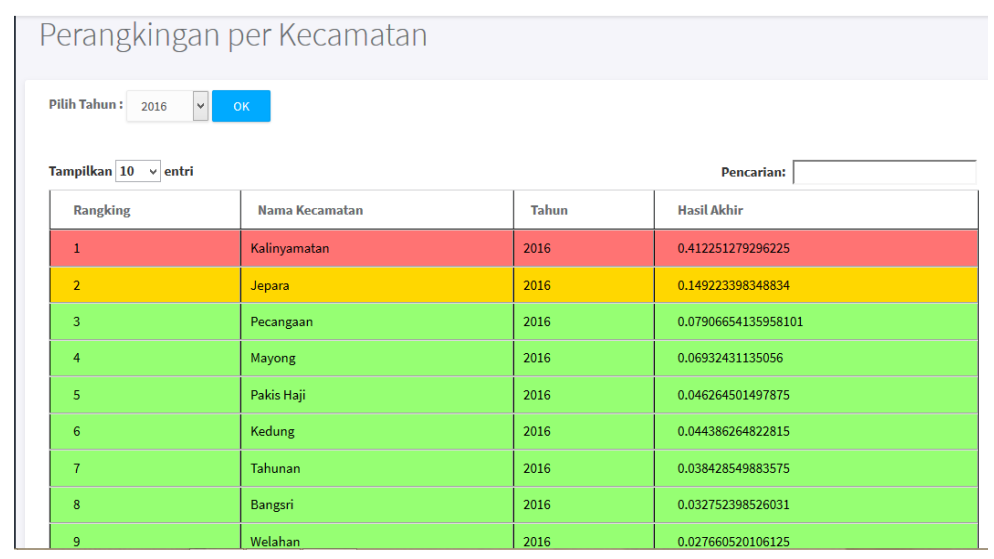

Gambar 7. Antarmuka Halaman Pemetaan Per Kecamatan

c. Antarmuka Peta Rekomendasi

Antarmuka ini menampilkan peta rekomendasi jenis tindakan operasi lalu lintas di tiap wilayah kecamatan berdasarkan warna, yaitu warna merah untuk razia, kuning untuk patroli, hijau untuk penyuluhan dan abu - abu untuk tanpa tindakan. Implementasi antarmuka halaman peta rekomendasi dapat dilihat pada Gambar 8. 


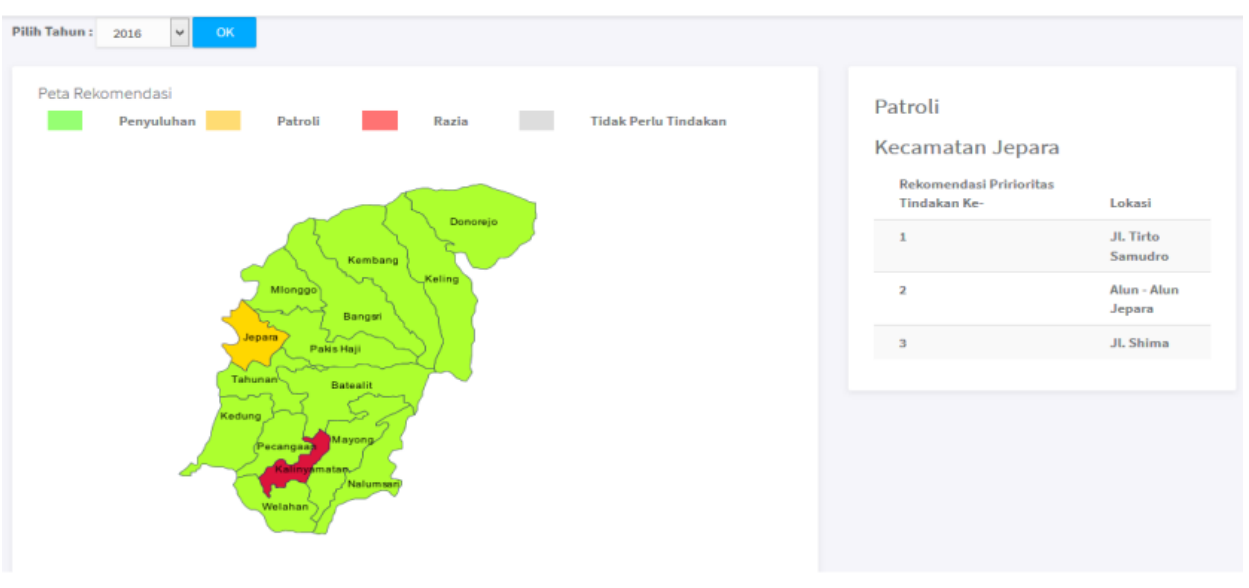

Gambar 8. Antarmuka Peta Rekomendasi

\subsection{Pengujian}

Pada sistem yang dibangun diberikan dua jenis pengujian yaitu pengujian fungsional secara blackbox dan pengujian penerimaan pengguna usability testing. Hasil dari blackbox testing menunjukkan semua butir pengujian terpenuhi dan tidak menunjukkan adanya kesalahan atau error. Hasil dari usability testing adalah Learnability memperoleh jawaban "Ya" untuk tiap pertanyaan. Efficiency memperoleh jawaban "Ya" untuk tiap pertanyaan. Memorability memperoleh jawaban "Ya" untuk tiap pertanyaan. Error memperoleh jawaban "Ya" untuk pertanyaan 1 dan 2 sedangkan untuk pertanyaan 3 pengguna menjawab "Tidak". Satisfaction memperoleh jawaban "Ya" untuk tiap pertanyaan, dengan demikian secara keseluruhan menunjukkan bahwa sistem dapat diterima oleh pengguna.

\section{KESIMPULAN}

Sistem penentuan jenis tindakan operasi lalulintas untuk Polres Jepara telah dibangun untuk membantu kasatlantas / kapolres dalam memutuskan jenis tindakan yang dilakukan berdasarkan hasil penghitungan metode AHP yang divisualisasikan dalam peta wilayah kabupaten Jepara. Sistem yang dibangun telah melalui blackbox testing dengan hasil memenuhi semua fungsionalitas yang disyaratkan. Dari hasil usability testing menunjukkan sistem dapat diterima oleh pengguna.

\section{DAFTAR PUSTAKA}

[1] Saragih, FA., 2017. Angka Pelanggaran Lalu Lintas Tidak Pernah Turun. [Online] Available at: http://otomotif.kompas.com/read/2017/10/22/153700315/angka-pelanggaran-lalu-lintas-tidakpernah-turun [Accessed 2017 Oktober 29].

[2] Saaty, T.L., 1990. How to make a decision : The Analytic Hierarchy Process. European Journal of Operational Research, 48, pp.9-26.

[3] Velasquez, Mark. 2013. "An Analysis of Multi-Criteria Decision Making Methods." International Journal of Operation Research Vol. 10, No. 2, 56-66

[4] Saaty, T.L., 2008. "Decision making with the analytic hierarchy process." International Journal of Services Sciences Vol. 1, No. 1, 83-98.

[5] Polri, 2012. Peraturan Kapolri No 80 Tahun 2012 Tentang Tata Cara Pemeriksaan Kendaraan Bermotor Di Jalan Dan Penindakan Pelanggaran Lalu Lintas Dan Angkutan Jalan.

[6] Markas Besar Kepolisian Negara Republik Indonesia Akademi Kepolisian, Fungsi Teknis Lalu Lintas, Kompetensi Utama, Semarang, 2009, hlm. 14

[7] Kota, P., 2012. Peta Kabupaten Jepara. [Online] Available at: http://peta-kota.blogspot.co.id/2012/01/petakabupaten-jepara.html [Accessed 21 February 2017].

[8] Marimin, M.S.P..D..I. (2004). Teknik dan Aplikasi Pengambilan Keputusan Kriteria Majemuk. Jakarta: PT. Gramedia Widiasarana. 